\section{CAUGHT IN CONFLICT}

Two seed banks are duplicating a now-inaccessible collection in Aleppo, Syria - but don't have the capacity to host the whole thing.

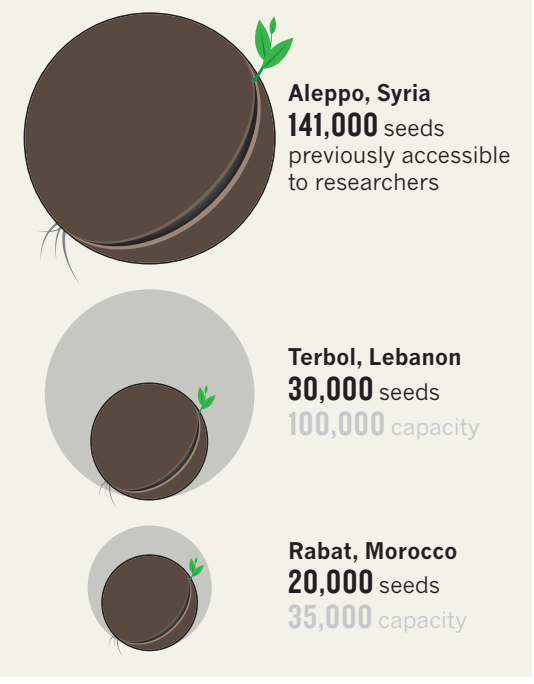

and so is ideal for testing how seeds grow in different ecosystems, he says.

But the move may also bring risks. The gene bank looks out on the Anti-Lebanon mountain range that forms much of Lebanon's border with Syria and is not far from the conflict. The Bekaa valley also hosts refugees fleeing the civil war.

Van Slageren ponders the potential for the conflict to spill into Lebanon. "You do have to wonder how their minds have been put at ease," he says. He notes that when ICARDA was set up in 1977, its headquarters were in Lebanon, but moved to Syria because of the Lebanese Civil War.

The latest move has also posed staff challenges. Many long-serving members were already close to retirement when ICARDA left Syria, says Amri, and so did not move to Terbol. And funding remains an issue, although ICARDA received significant financial help with the move from various agencies, including the CGIAR Consortium, a global partnership aimed at alleviating poverty and hunger.

The current capacities of the banks in Terbol and Rabat - 100,000 and 35,000, respectively - do not add up to enough to duplicate all 141,000 seeds, representing some 700 species, that Aleppo holds, let alone take on new seeds (see 'Caught in conflict').

Amri is confident. Among other things, previous unrest in Lebanon did not disrupt ICARDA's Terbol station. "It's gone through 20 years of fighting, and we never had any problems," he says. Still, the Moroccan talks wistfully of his years working in Syria. "We enjoyed our lives in Aleppo. It was one of the nicest places to live - wonderful people and a good environment for research at ICARDA." -

\title{
ETHICS
}

CRISPR concerns

\section{UK bioethics panel eyes the implications of gene editing.}

\section{BY HEIDI LEDFORD}

$\mathrm{F}$ rom designer babies to engineered mosquitoes, advances in genome-editing technologies such as CRISPR-Cas9 have raised the possibility of tremendous scientific advances - and serious ethical concerns.

In a preliminary 130-page report released on 30 September, the influential London-based Nuffield Council on Bioethics announced that two applications of the technology demand further attention: genome editing in human embryos and in livestock.

It will probably be years before genome editing is used in human reproduction, but it is clear from speaking to scholars and the public that ethical concerns about edited human embryos are at the forefront of many minds, says Karen Yeung, a legal scholar at King's College London and a member of the Nuffield working group. "Human reproductive applications are perhaps the most talked about or controversial area."

The revelation last year that researchers had used CRISPR-Cas9 in human embryos turned a public spotlight on gene editing's potential applications in human reproduction. That study used non-viable embryos for research purposes only ( $P$. Liang et al. Protein Cell 6, 363-372; 2015), but it launched a public debate about whether and how such technologies should be deployed in people.

It also sparked a spate of soul-searching at national academies and agencies around the world. The US National Academies of Sciences, Engineering and Medicine are compiling a report — due in early 2017 — on human applications of genome editing. And an independent group of European ethicists is speaking to the European Commission about forming a steering committee to ensure that CRISPR methods are safe and reliable before being used for medical purposes.

The Nuffield Council also aims to finish its report on ethical questions in human reproduction in early 2017. The working group will focus on the implications of using gene editing to address genetic diseases, says Yeung. Such applications are years away, she says, but are important enough to warrant an early focus. Tinkering with embryos destined to be implanted is against UK law, she notes. If the group finds strong moral arguments in favour of using genome editing to prevent disease, it could take a long time to change that regulation.

The working group would also have to wrestle with drawing the line between ethically acceptable and unacceptable uses, Yeung says.

That discussion is particularly important, says Alta Charo, who studies law and ethics at the University of Wisconsin-Madison. Scientists and ethicists usually focus on serious genetic disorders, but the public conversation often wanders into murkier territory, such as intelligence augmentation. "The lay press tends to do all of these covers about designer babies," she says. "They tend to focus on the things that are the least likely to be genetically determined, but capture our

imaginations the most."

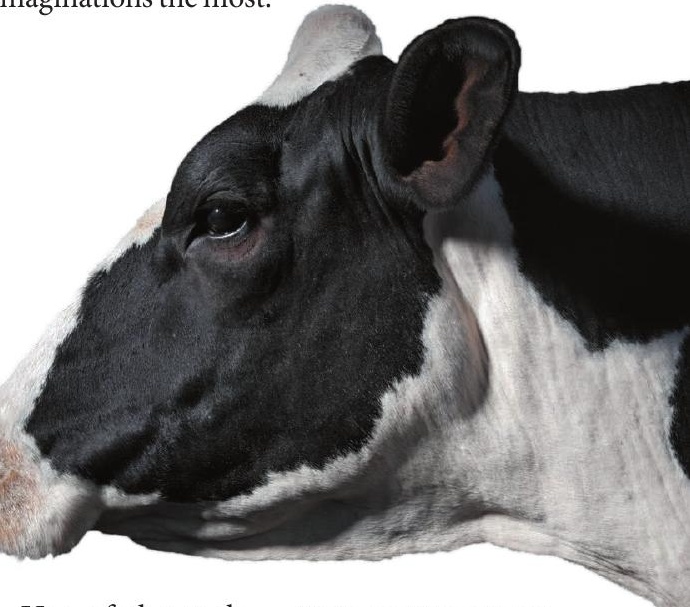

Use of the technology in livestock comes with issues

Cattle could be subject to gene editing - one topic being considered of its own. These by a UK bioethics group. include concerns about animal welfare, and whether and how meat from such animals should be labelled. Labelling is a particularly vexing issue, given that gene-edited animals can be indistinguishable from their natural counterparts with the same mutation.

"Labelling and classification depend on traceability," says John Dupré, a philosopher of science at the University of Exeter, UK, and a member of the Nuffield working group. "Genome editing makes analytical verification of this difficult or impossible."

But some edited livestock - including cattle without horns and pigs that are resistant to disease - are already under development. And the working group felt that there had been comparatively little public discussion of the matter, says Peter Mills, assistant director of the Nuffield Council. "In the livestock, the technology there is pretty much ready to go," he says. "That was something from our point of view that needs to be brought to public attention." 